\title{
THE ECONOMY AND FOREIGN TRADE OF CHINA
}

\author{
LIANG-SHING FAN *
}

After two decades of the U.S. policy of containment, China and the United States have entered into a new relationship, occasioned by China's ping pong diplomacy and the Nixon-Kissinger policy of detente. Those developments make this an auspicious moment for reappraisal of China as an economic entity and as a potential trade partner for this country.

\section{An Economic Profile of China}

\section{A. China's Resources ${ }^{1}$}

China's enormous land (3.7 million square miles) contains many valuable resources, of which the most important are the human resources. Nearly 800 million people crowd the coastal and central regions of China, with a sparsely populated inner expanse along the Sino-Soviet borders. The literacy rate has been increasing rapidly as a result of compulsory education, widespread adult education, and the simplification of Chinese characters. The contribution of educated manpower to the miracle of economic growth in otherwise resourcepoor Japan demonstrates the promise 800 million educated people hold for the development of China.

China seems to be self-sufficient in many mineral resources, especially the coal-iron base. As early as 1965 , the P.R.C. produced nearly 300 million tons of coal, and its output has been increasing ever since. There are more than seven coal mining areas, each producing between 10 and 20 million tons. The biggest production center is the Liaoning Province in Manchuria. China has been a steady supplier of coking coal to Japan since the early 1960's, a relationship likely to continue unless the energy shortage in Japan is alleviated.

Although the absolute volume of oil output is still meager, China has been virtually self-sufficient in most of its oil needs, so that oil from the Taching oil field in Manchuria has also been offered to Japan. In addition, China has been producing millions of tons of shale oil in Manchuria and Kwantung for many years. Some exchange of technical know-how with the U.S. may soon be mutually beneficial as the U.S is on the verge of multi-billion dollar shale exploitation in Colorado, Wyoming, and Utah.

In metal production, China's most important iron-steel complex is Ansham in Manchuria, with a capacity of more than 6 million tons per year. The central China Wuham center and the Paoton center are two other major complexes.

\footnotetext{
*Professor of Economics, Colorado State University.

${ }^{1}$ See generally 1-2 Joint Economic Comm., 90th Cong., 1st Sess., An Economic Profile of Mainland China (Comm. Print 1967) [hereinafter cited as Economic Profile]; JoInt Economic Comm., 92d Cong., 2d Sess., People's Republic of China: An Economic Assessment (Comm. Print 1972) [hereinafter cited as Economic Assessment].
} 
Shanghai, the largest industrial city of China, also has a major steel production facility. Nevertheless, the estimated production of 18 million tons of crude steel in 1970 is low when compared to major industrial countries, so the P.R.C. still is importing quality special steels from Japan and East European countries. As the nation's industrialization continues, China's steel output should be significantly increased, creating the potential for technological cooperation with the U.S. in the near future.

China has been an exporter of tin, tungsten, manganese, antimony, mercury, and molybdenum, but the continued exportability of such commodities depends upon Chinese domestic needs and stockpile policies. China has experienced shortages of nickel, chromite, and copper in the past.

In nonmetal resources, China produces asbestos and cement ${ }^{2}$ for domestic use. Chemical fertilizer production tripled from 1960 to 1970 to an estimated 7.4 million tons, but fertilizer is still imported from other countries. China is the world's number two producer of salt, second only to the United States; Japan generally imports the Chinese surplus.

Finally, the Chinese explosion of nuclear devices can reasonably be assumed to indicate the production of some radioactive materials in substantial quantity.

\section{B. China's Industrial Production ${ }^{3}$}

The relative share of national production contributed by the machinery sector, which is one of the best indicators of industrial development, increased from 0.13 per cent of total industrial production in 1952 to 20 per cent in

\section{TABLE I}

Chinese Industrial Production 1949-1970

\begin{tabular}{|c|c|c|}
\hline Year & $1949=100$ & Characteristics of Period \\
\hline 1949 & 100 & \\
1950 & 126 & Economic Rehabilitation \\
1951 & 168 & \\
1952 & 206 & \\
1953 & 258 & The First Five-Year Plan \\
1954 & 295 & \\
1955 & 297 & \\
1956 & 368 & The Greap Leap Forward \\
1957 & 403 & \\
1958 & 529 & Soviet-Sino Rift (mid-1960) \\
1959 & 668 & \\
1960 & $649-658$ & \\
\hline
\end{tabular}

${ }^{2}$ The Fushan Cement Plant in Manchuria uses a by-product of oil shale as raw material, suggesting the possibility of recycling oil shale waste.

${ }^{3}$ See generally 1 Economic Profile 269; Economic Assessment 61.

${ }^{4}$ Adapted from Economic Assessment 61-66. 
TABLE I cont.

\begin{tabular}{|c|c|c|}
\hline Year & $1949=100$ & Characteristics of Period \\
\hline 1961 & $430-411$ & \\
1962 & $435-453$ & Recovery and Readjustment \\
1963 & $478-504$ & \\
1964 & $535-571$ & \\
1965 & $597-646$ & \\
1966 & $663-727$ & \\
1967 & $538-598$ & Cultural Revolution and its \\
1968 & $582-655$ & Aftermath \\
1969 & $686-783$ & \\
1970 & $801-926$ & \\
\hline
\end{tabular}

TABLE II

Chinese Industrial Products

$1949-1970^{5}$

\begin{tabular}{|c|c|c|c|c|c|c|c|c|}
\hline Product & $\begin{array}{c}\text { Pre- } \\
1949(H) *\end{array}$ & 1949 & 1957 & $\begin{array}{c}1958- \\
1960(\mathrm{H})^{*}\end{array}$ & $\begin{array}{c}1961- \\
1962(\mathrm{~L}) \dagger\end{array}$ & 1966 & $\begin{array}{c}1967- \\
1968(\mathrm{~L}) \dagger\end{array}$ & 1970 \\
\hline $\begin{array}{l}\text { Electricity } \\
\text { (billion KWH) }\end{array}$ & 6.0 & 4.3 & 19.3 & 47.0 & 30.0 & 47.0 & 41.0 & 60.0 \\
\hline $\begin{array}{l}\text { Coal } \\
\text { (million MT }\end{array}$ & 62.0 & 32.4 & 130.7 & 300.0 & 170.0 & 240.0 & 190.0 & 300.0 \\
\hline $\begin{array}{l}\text { Crude Oil } \\
\text { (million MT) }\end{array}$ & 0.3 & 0.1 & 1.5 & 4.6 & 4.5 & 10.0 & 10.0 & 18.0 \\
\hline $\begin{array}{l}\text { Crude Steel } \\
\text { (million MT) }\end{array}$ & 0.9 & 0.2 & 5.4 & 13.0 & 8.0 & 13.0 & 10.0 & 17.0 \\
\hline $\begin{array}{l}\text { Aluminum } \\
\text { (thousand MT) }\end{array}$ & - & - & 39.0 & 80.0 & 60.0 & 125.0 & 145.0 & 230.0 \\
\hline $\begin{array}{l}\text { Cement } \\
\text { (million MT) }\end{array}$ & 2.3 & 0.7 & 6.9 & 10.6 & 5.5 & 12.0 & 10.2 & 13.0 \\
\hline $\begin{array}{l}\text { Machine Tools } \\
\text { (thousand units) }\end{array}$ & 5.4 & 1.6 & 28.3 & 38.0 & 25.0 & 48.0 & 40.0 & 50.0 \\
\hline $\begin{array}{l}\text { Trucks } \\
\text { (thousand units) }\end{array}$ & - & - & 7.5 & 19.4 & 1.0 & 47.0 & 31.0 & 75.0 \\
\hline $\begin{array}{l}\text { Tractors } \\
\text { (thousand units) }\end{array}$ & - & - & - & 10.8 & 6.7 & 17.6 & 15.3 & 21.0 \\
\hline $\begin{array}{l}\text { Locomotives } \\
\text { (units) }\end{array}$ & 22.0 & - & 167.0 & 600.0 & 25.0 & 140.0 & 200.0 & 280.0 \\
\hline $\begin{array}{l}\text { Paper } \\
\text { (million MT) }\end{array}$ & 0.2 & 0.1 & 0.9 & 1.4 & 0.9 & 1.6 & 1.5 & 1.8 \\
\hline $\begin{array}{l}\text { Chemical Fertilizer } \\
\text { (million MT) }\end{array}$ & 0.2 & 0.03 & 0.8 & 2.5 & 1.4 & 5.5 & 4.0 & 7.0 \\
\hline $\begin{array}{l}\text { Cotton Cloth } \\
\text { (billion meters) }\end{array}$ & 2.8 & 1.9 & 5.1 & 7.5 & 4.0 & 6.0 & 4.8 & 7.5 \\
\hline
\end{tabular}

*(H) High

$\dagger(L)$ Low

†Metric Tons

'Adapted from Central Intelligence Agency, People's Republic of China Atlas 69 (1971). 
1970. The machinery sector provides most of China's needs, though its technical capabilities still lag behind most of the industrialized world, including Japan. Accordingly, China may be in the market for technical know-how in the near future.

China's light industry, of which the main subsectors are textiles and food processing, is one of the economy's slowest growing sectors. Even though its output more than doubled from 1952 to 1970, its relative share of production declined from 56 per cent of total industrial output to 29 per cent during the same period. The decline resulted from P.R.C. policies which concentrated fuel, power, machinery, and materials for faster industrialization.

In sum, Chinese industrial production has seen great growth as compared to the pre-communist period. As Tables I and II indicate, however, industrial policy has been subjected to drastic changes due to political developments such as the Great Leap Forward and the Cultural Revolution.

\section{China's Transportation System ${ }^{6}$}

When the communists took control of the Chinese government, they inherited an underdeveloped and partially destroyed transportation system. Since then, the P.R.C. has put major emphasis on development of extensive railway and highway systems, as well as the improvement of the inland waterways. ${ }^{7}$ In twenty years, railway mileage increased 80 per cent, highway mileage 600 per cent, and navigable waterways doubled. For long hauls, the railway is still the dominant means of transportation, but the phenomenal expansion of the highway network in the West, as between Sinkiang and Tibet, indicates a Chinese effort to open up the inland sector. Trucking supplements the railway and waterways in the short hauls.

Inland waterways have provided major East-West connections, and there are many major industrial centers along the Yangtze River. For foreign visitors who are accustomed to the modern airlines of the West, the Chinese air transportation system is still rather primitive. It has not yet attempted to open overseas routes, and the number of modern aircraft is still limited. Nevertheless, a recent purchase of Boeing 707's and British Tridents may be an indication of future efforts. The comparative advantage of the U.S. in manufacturing airplanes and electronic guidance systems suggests the possibility of future trade as China's air transportation system develops.

${ }^{6}$ For a detailed discussion and evaluation of the transportation network, see Vetterling \& Wagy, China: The Transportation Sector, 1950-71, in Economic AsSESSMENT 147.

The Chinese Transportation Network (Mileage in Kilometers)

\begin{tabular}{|l|c|c|c|c|}
\hline Mode of Transportation & 1950 & 1960 & 1970 & 1971 \\
\hline Railway (operation) & 22,512 & 33,000 & 40,000 & 41,000 \\
Highway (in operation) & 99,600 & 500,000 & 650,000 & NA \\
Inland Waterway & 73,615 & 168,000 & NA & NA \\
\hline
\end{tabular}

Adapted from $i d$. at 178 . 


\section{China's Agricultural Development ${ }^{8}$}

Incredibly, China's agriculture feeds one-fourth of the world's population with only seven or eight per cent of the world's cultivated land. Land usage is very heavy and the marginal product of labor low, so that 80 per cent of the population still depend on agriculture for their livelihood. There is about 0.35 acre of cultivated land for each person in China as compared with 1.9 acre per person in the United States. Since the land's salinity makes its reclamation difficult, the regime has emphasized the intensive cultivation of available land. Measures such as irrigation system development, flood control, water conservation, and increased fertilization have been used. Chinese farmers in the South are the beneficiaries of a climate and annual rainfall which allow three crops a year, though the fertility of the soils has been degraded by long years of intensive cultivation.

The agricultural policy of the communist regime can be divided into two stages: 1949-1961 and the new strategy since 1962. During the first decade of the regime, primary emphasis was placed upon industrial development, so that only a minor share of capital investment was directed toward the agricultural sector. Instead, government action concentrated on the socialization of the agricultural structure through the collectivization of peasant households. The final stroke of socialization took place during the Great Leap Forward period with the establishment of "people's communes," which were designed to be self-sustaining units. They established local industrial plants, managed all farm supplies, consumer goods distribution, and, most important of all, the distribution of income for members. By 1964, virtually 99 per cent of Chinese peasants were in communes, which numbered 74,000.

The agricultural output had increased rather slowly, but the policy to "leap forward" in 1958 by communization and drastic mobilization of the labor force into overtime work for stepped-up production was an unmitigated disaster. Stories of thousands of backyard blast furnaces and billions of man days on public works were legendary. The commune life was not readily accepted by individualistic, family oriented Chinese peasants. The resulting lack of incentive, along with two consecutive years of unfavorable weather, caused disastrous crop years in 1959-1961.

There was a reversal of policy in 1962, accompanied by more normal weather. Private plots for vegetables and livestock for sale in markets were reactivated. The Tenth Plenum of the Chinese Communist Party in 1962 adopted an "agriculture first" policy which included priority for state investment in the agricultural sector, an increase in chemical fertilizer imports, greater production of farm machinery, and importation of grains. Unfortunately, the unexpected failure of the Summer Reservoir to control the 1963 Yellow River flood in the North China Plain caused the new strategy to fail. After that setback, another new policy was developed-to concentrate state investment in the high yield

\footnotetext{
${ }^{8}$ The most comprehensive work in a historical perspective by an American author is $D$. $H$. Perkins, Agricultural Development in China, $1368-1968$ (1969). This section of the article is based on Larsen, China's Agriculture Under Communism, in 1 Economic Profile 197; and Erisman, China: Agriculural Development 1947-71, in 1 ECoNomic AsSESSMENT 112.
} 
farmland of the South. The subsequent Cultural Revolution of 1966-1969 did not threaten agricultural development as much as did Mao's Great Leap Forward because the private plots were left intact for material incentive, and other agriculturally oriented industries kept up their outputs. Since 1970, the People's Liberation Army has kept the Red Guard from interfering with the policy of "agriculture first."

As a result of the policy of improving the high yield fields, irrigated lands increased from 7.6 million hectares to 13 million hectares during 1963-1971, whereas there had been a meager 1.1 million hectare increase during 1957-1963. The trend toward high yield farmland is expected to continue until at least onethird of China's farmland, or 36 million hectares, is irrigated. The irrigation movement has been accompanied by an increase in the production of pumping equipment, high yield varieties, rural electric systems, agricultural tools, tractors, chemical fertilizers, and pesticides. ${ }^{9}$ The resulting potential for export to the P.R.C. of plants and chemical fertilizers should not be neglected.

\section{E. Human Resources}

\section{Population}

China's population policy has undergone many modifications in the past twenty-five years. While the pressure of food production is undoubtedly important, political factors predominate in this area. Chinese attitudes toward family life determine the effectiveness of birth control measures. Thus, even though the P.R.C. has undertaken three campaigns of population limitation, birth control efforts have had little effect, especially in rural areas, where 80 per cent of the Chinese population still live. Even though some experts expect a gradual decline in fertility and mortality in the next several decades, it is estimated that China's population will increase to 1.3 billion by $1990 .^{10}$

\section{Education ${ }^{11}$}

The shock of the Cultural Revolution did not interrupt the continuity of Chinese scientific advancement in more applied fields.. Emphasis in scientific research is placed on the innovative adaptation of currently available knowledge, but there is also some basic research. The political ideology of the Communist Party is the dominating influence in Chinese society, including science and technology. The famous open public confession suffered by the chairman of the Academy of Sciences, Mr. Kuo, and many other top intellectuals, has been widely publicized, ${ }^{12}$ but many recent visitors feel that the impact of such ideological attacks was not as great as anticipated.

Although scientific achievement escaped many of the effects of the Cultural Revolution, the educational system in general suffered a loss of several years stoppage in certain areas. ${ }^{13}$ Even before the Cultural Revolution, the process

\footnotetext{
${ }^{9}$ See Erisman, supra note 8, at 139-40.

${ }^{10}$ Aird, Population Policy and Demographic Prospects in the People's Republic of China, in Economc ASSESSMENT 220.

11 Orleans, China's Science and Technology: Continuity and Innovation, in ECONOMIC ASSESSMENT 185.

12 Id. at 193 .

${ }^{13} I d$. at 219 .
} 
of shortening China's precollege education had begun. Now only nine or ten years are spent in preparation for college, while higher education typically takes only two or three years, depending upon the field of study. More than 70 per cent of college study is now spent on professional education.

As a result, there were approximately 600,000 engineers and 110,000 scientists in China as of 1970 . One of the most publicized achievements of Chinese science and technology has been the construction of nuclear devices and missiles for defense. More than ten nuclear weapons had been tested as of 1972, and two satellites were put into orbit. The P.R.C. is eager to absorb the advanced knowledge of the West, and this decade will see more exchange of information and contacts among scientists.

\section{F. Growth of the Economy ${ }^{14}$}

Estimates of China's growth rate between 1957 and 1970 vary from 3.1 per cent per year (1.0 per cent on per capita basis) to 3.7 per cent ( 1.6 per cent per capita). Such rates are low when compared to Taiwan ( 8.9 per cent, 5.8 per cent per capita), Japan (10.5 per cent, 9.5 per cent per capita), Thailand (8.7 per cent, 5.4 per cent per capita), and South Korea (8.1 per cent, 5.3 per cent per capita). China's growth rate is comparable to that of India ( 3.4 per cent, 1.2 per cent per capita).

\section{II}

\section{International Trade With China ${ }^{15}$}

\section{A. Pre-Sino-Soviet Rift: 1950-1959}

After Mao's revolution, China looked to the communist bloc countries, especially the U.S.S.R., for trading partners. The embargo imposed by Western nations on certain materials at the time of the Korean War and the unwillingness of many countries to extend export credits to the P.R.C. also contributed to the early concentration of Chinese trade with the Soviet Union. Since rapid industrialization was a basic economic policy of the P.R.G., there were large-scale imports of complete plants from the Soviet Union. Such construction agreements between the P.R.C. and the U.S.S.R. during the 1950's totaled 291, involving $\$ 3,275$ million. ${ }^{16}$

How China financed those imports is an interesting question. Estimates of the total amount of credit extended by the Soviet Union to China vary from 5,300 million rubles to 8,960 million rubles, depending upon the exchange rates used and the interpretation of the loan agreement. ${ }^{17}$ When the export-import

\footnotetext{
14 Eckstein, Economic Development Prospects and Problems in China, 402 Annals 109 (1972); Liu \& Yeh, Chinese and Other Asian Economies: A Quantitative Evaluation, 63 AM. Econ. Rev. Proc. No. 2, at 215 (1973). See generally S. Ishikawa, National Income Formulation in Mainland China (1965); T. Liu \& K. Yeh, The Economy of the Chinese Mainland: National Income AND ECONOMIC Development, 1933-59 (1965).

15 See generally A. Eckstein, Communist China's Economic Growth and Foreign Trade: Implications for U.S. Policy (1966); F. Mah, The Foreign Trade of Mainland China (1971).

${ }^{16}$ Price, International Trade of Communist China, 1950-62, in 2 EConomic Profile 591.

${ }^{17}$ See Eckstein, supra note 14, at 154-61.
} 
data are carefully analyzed, it appears that the Soviet Union became a net importer from China as early as 1956. The total trade surplus of China during 1956-1963 was 5,360 million rubles, which was almost identical to the total Soviet credit extended during 1950-1960. Thus it would seem likely that China financed plant imports from the U.S.S.R. as a captive customer of the latter, subject to unfavorable terms of trade and stingy Soviet credit terms. ${ }^{18}$

China's trade flows during this period expanded from $\$ 350$ million to $\$ 3$ billion, and the Soviet Union accounted for about 70 per cent of P.R.C. trade. Major items imported from the U.S.S.R. were machinery and equipment, while China exported foodstuffs, raw materials, and consumer goods. Eastern Europe also supplied machinery and equipment to China, and China reciprocated with raw materials and foodstuffs. Some small trade surpluses with Asian communist countries were, in reality, Chinese aid to those countries, but such aid represented less than 10 per cent of the total Chinese trade with communist countries. China's trade with noncommunist countries during this period fell below onequarter of total P.R.C. trade and it reached barely 30 per cent in 1959.

\section{B. The Shifting of Trading Partners: 1960-1965}

The open conflict of mid-1960, climaxed by the U.S.S.R.'s withdrawal of technical aid, prompted China to seek new trading partners in the early 1960's; P.R.C. trade with the U.S.S.R. declined from $\$ 1.7$ billion in 1960 to only $\$ 450$ million in 1964. East European communist countries, with the exception of Albania, sided with the U.S.S.R. in the conflict, so that China's trade with those nations also declined from $\$ 645$ million in 1960 to $\$ 160$ million in 1964 . Concomitantly, China's trade with noncommunist countries jumped from $\$ 1.37$ billion in 1960 to $\$ 2.12$ billion in 1964, while trade with Asian communist countries increased from $\$ 310$ million to almost $\$ 500$ million. ${ }^{19}$

During this period, China was forced for the first time to import large quantities of grain, due to the failure of the Great Leap Forward. As China shifted to its "agriculture first" policy, imports of chemical fertilizer were also increased. Major exporters of grain to China were Canada and Australia, while Japan and West European nations provided the bulk of imported chemical fertilizers. China also began at this time to import complete plants from Japan and Western Europe, along with technical assistance and credit extension. These actions enabled China to have access to modern technology without relying on the U.S.S.R. and other communist countries.

While there was a steady flow of grain import during the 1960's, there was also substantial foodstuff export during the same period. Since the new strategy emphasized the high yield Southern China farmland, China was able to export

\footnotetext{
${ }^{18}$ Usack \& Batsavage, The Intermational Trade of the People's Republic of China, in EcoNomic Assessment 345. During this period, the consumer goods imports declined from 12.8 per cent to 6.3 per cent while producer goods imports increased to 93.7 per cent by 1958 . Exports of agricultural products declined from 90.7 per cent in 1950 to 72.5 per cent in 1958. That means the industrial and mining products increased from 9.3 per cent to 27.5 per cent by 1958 . However, a more interesting change is the relative decline in raw agricultural products from 57.5 per cent to 35.5 per cent. See F. MAH, supra note 15, at 29.

${ }^{19}$ Usack \& Batsavage, supra note 18 , at 347.
} 
rice from the South at the same time it was importing wheat for the wheat consuming Northern Chinese. This exchange was always to the advantage of rice exporters because of the relatively high rice prices in the world market.

\section{Trade During 1966-1970}

The economic recovery from the disasters of the Great Leap Forward was followed by the shock of the Cultural Revolution. By 1966, total P.R.C. trade had reached its previous peak of $\$ 4.29$ billion. The domestic disruptions of the Cultural Revolution did not have a great impact on foreign trade even though a 10 per cent reduction in trade was registered at the height of the Red Guard activities in 1968. The restoration of order in 1969 permitted trade to rise again, and it reached a record high of $\$ 4.5$ billion in 1971 .

The composition of trade commodities during this period reveals a significant shift from the import of foodstuffs to manufactures, especially iron, steel, and nonferrous metals. Imports of iron and steel manufactures expanded from $\$ 145$ million in 1965 to $\$ 390$ million in 1970 , while imports of nonferrous metals leaped from a mere $\$ 50$ million to $\$ 210$ million. On the export side, there was very little change in composition: foodstuffs and crude materials $\$ 1.08$ billion in 1970), and chemicals and manufactures (\$965 million in 1970), each occupied around one-half of total exports. ${ }^{20}$

There was continuous development in trade with the noncommunist world in 1966-1970. Trade with developed countries in the noncommunist world increased from 39 per cent in 1965 to 53 per cent in 1970. Total Chinese trade with noncommunist countries exceeded 80 per cent by 1970. Sino-Soviet trade was a negligible 1 per cent of China's trade with the outside world in 1970. There was, however, a slight increase in trade with East European countries from 1964 to 1970 (from 5 to 8 per cent of total Chinese trade), but it was still well below the pre-Sino-Soviet rift peak of 1958 .

\section{The Balance of Trade: 1961-1971}

\section{Trade With Noncommunist Countries}

Canada and Australia were successful in selling grains to China during the 1960 's while they imported very little from China. ${ }^{21}$ Thus it is no wonder that

\begin{tabular}{|c|c|c|c|c|c|c|}
\hline & ANCE OF & $\begin{array}{l}\text { DE AGAI } \\
\text { (in millio }\end{array}$ & $\begin{array}{l}\text { Noncomm } \\
1971 \\
\text {.S. dollars }\end{array}$ & Toun & & \\
\hline & Export & $\begin{array}{l}1961 \\
\text { Import }\end{array}$ & Net & Export & $\begin{array}{l}1965 \\
\text { Import }\end{array}$ & Net \\
\hline $\begin{array}{l}\text { EEC* } \\
\text { EFTA† } \\
\text { Japan } \\
\text { Australia } \\
\text { Canada } \\
\text { Hong Kong } \\
\quad \text { and Macao }\end{array}$ & $\begin{array}{r}147.3 \\
118.4 \\
30.9 \\
7.1 \\
3.2 \\
\\
180.0\end{array}$ & $\begin{array}{r}109.2 \\
58.9 \\
16.7 \\
161.4 \\
122.8 \\
\\
17.3\end{array}$ & $\begin{array}{l}+38.1 \\
+\quad 59.5 \\
+\quad 14.2 \\
-154.3 \\
-119.6 \\
+162.7\end{array}$ & $\begin{array}{r}194.0 \\
132.0 \\
225.0 \\
26.8 \\
13.4 \\
406.3\end{array}$ & $\begin{array}{r}231.0 \\
113.0 \\
245.0 \\
198.0 \\
67.5 \\
12.5\end{array}$ & $\begin{array}{l}-\quad 37.0 \\
+\quad 19.0 \\
-\quad 20.0 \\
-171.2 \\
-\quad 54.1 \\
+393.8\end{array}$ \\
\hline
\end{tabular}


Canada now strives to import from China in order to reduce its chronic trade surplus. Similarly, Japan has been the major exporter of industrial output to China, creating a substantial trade imbalance, so that the future of Sino-Japanese trade depends upon Chinese exportation of more coking coal, petroleum, and foodstuffs to Japan. With the worldwide shortage, China may refrain from providing resource-poor Japan with such Chinese products.

European countries, which export considerable amounts of industrial products to China, are at a competitive disadvantage vis-à-vis Japan because of the latter's lower transportation costs and greater demand for Chinese foodstuffs and handicrafts. Nevertheless, the Chinese are eager to avoid reliance on a single trade partner, so there is good reason to expect a continuous, moderate growth of West European trade with China.

China's trade with less developed countries shows a continuous trade surplus, but the total sum has been rather steady, around $\$ 800$ million. The important feature of this trade is that China exports manufactured products and imports crude materials, mainly rubber and fiber. As a self-proclaimed champion of the "Third World," China is eager to extend her influence through trading with many countries in Southeast Asia, the Near East, South Asia, and Africa.

\section{Trade With Communist Countries}

The ideological conflict with the Soviet bloc has caused a drastic decline in trade. Chinese imports from the U.S.S.R., which amounted to $\$ 954.6$ million in 1959 , dwindled to a meager $\$ 20$ million in 1970 . Chinese exports to the U.S.S.R. were $\$ 1.1$ billion in 1959 , but dropped to only $\$ 25$ million by 1970 . Trade with East Germany, Czechoslovakia, Poland, Hungary, and Bulgaria has also declined, but not as drastically as Sino-Soviet trade. Trade with Romania, Albania, and Cuba has either increased or been maintained at a steady rate.

\section{E. China's Foreign Aid Program ${ }^{22}$}

China's foreign aid is aimed at consolidating and expanding its influence over other communist and Third World countries. Accordingly, China has extended aid to many less developed countries since 1956, especially since 1970. Out of $\$ 2.2$ billion in economic aid expended from 1956 to 1971 , nearly 55 per cent was spent during 1970 and 1971 alone. In 1971, \$295 million in aid, out

\begin{tabular}{|l|r|r|r|r|r|r|}
\hline & \multicolumn{3}{|c|}{1969} & \multicolumn{3}{c|}{1971} \\
& Export & \multicolumn{1}{c|}{ Import } & \multicolumn{1}{c|}{ Export } & \multicolumn{1}{c|}{ Import } & Net \\
\hline EEC* & 268.5 & 297.9 & -29.4 & 272.0 & 323.0 & -51.0 \\
EFTA† & 160.0 & 171.8 & -11.8 & 152.0 & 183.6 & -31.6 \\
Japan & 234.0 & 390.0 & -156.0 & 322.0 & 578.0 & -256.0 \\
Australia & 33.6 & 120.0 & -86.4 & 39.0 & 27.0 & +12.0 \\
Canada & 25.2 & 112.8 & -87.6 & 22.0 & 195.0 & -173.0 \\
Hong Kong & 450.0 & 6.0 & +444.0 & 550.0 & 11.0 & +539.0 \\
\hline
\end{tabular}

*European Economic Community.

†European Free Trade Association (1970 data is used instead of 1971).

Source: compiled from tables in J. DelEyne, The Chinese Economy 159-60 (1973).

${ }^{22}$ See Tansky, Chinese Foreign Aid, in Economic Assessment 371. 
of a total $\$ 467$ million, was given African countries. East Asian and South Asian countries received $\$ 89$ million. Although the total Chinese aid given in 1971-nearly half a billion dollars-was only about a quarter of U.S. aid, it is a considerable amount relative to China's gross national product. Since 1970, when Chinese aid increased substantially, the P.R.C. has even extended support to monarchies and anti-communist military juntas. ${ }^{23}$

Chinese aid has an immediate impact because of its nature. The Chinese almost always send commodities which the recipient countries can use at once to attack pragmatic problems or trade deficits. The completion of the Tan-Zam Railroad, a monumental contribution to the poor transportation systems of East Africa, is an example. In contrast, billions of dollars of U.S. aid have been spent without any visible consequences. Pursuant to the policy of providing solutions to immediate problems, China has emphasized the sending of experts as part of its aid program. In 1971, there were 18,700 Chinese economic technicians in less developed countries. ${ }^{24}$

\section{F. China's Trade With the United States}

Since the current regime was established in 1950, the United States has been the only country without official trading relationships with the P.R.C. As such, there are no official statistics of trade with China covering the period from 1950 to 1971. Since the relaxation of trade barriers, the major exchange between China and the U.S. has been of agricultural products. American exports to China amounted to well over $\$ 0.7$ billion in 1973 , with the major commodities being grains ( $\$ 110$ million), feed grains ( $\$ 132$ million), soybeans ( $\$ 61$ million), and cotton ( $\$ 100$ million). In addition, China has imported hundreds of items, such as hair, crude fur, and bristles, which appear to be ingredients for merchandise in Chinese stores, although trade did not exceed $\$ 8$ million for any of these items.

The dramatic increase in Sino-American trade shown in Table III indicates that the U.S. now recognizes the huge market China can provide for American goods. As this article has indicated, the Chinese economy makes the P.R.C. a potential trading partner of the United States in many areas other than agriculture. Whether that potential will be realized will depend on the further development of political relations as well as the solution of credit problems which will ensue, should the 1973 trade imbalance be maintained.

TABLE III

U.S. Agricultural EXPORTS AND IMPORTS

$1972-1973^{25}$

(in million U.S. dollars)

\begin{tabular}{|c|c|c|}
\hline & Export & Import \\
\hline 1972 & $\$ 61.3$ & $\$ 16.4$ \\
1973 & 575.0 & 21.4 \\
\hline
\end{tabular}

${ }^{23}$ Id. at 374 .

24 Id. at 376.

${ }_{25}$ The author is grateful to Dr. Melvin Skold for his assistance in obtaining data from the Foreign Agricultural Service, U.S. Department of Agriculture. 